\title{
Applying a fish biological integrity index to a restoration plan in a small-sized river: case study in the Kamisaigo River
}

\author{
R. Lopa ${ }^{1}$, H. Hayashi ${ }^{2}$, Y. Shimatani ${ }^{2}$ \& J. Nakazima ${ }^{2}$ \\ ${ }^{I}$ Department of Urban and Environmental Engineering, \\ Graduate School of Engineering, Kyushu University, Japan \\ ${ }^{2}$ Department of Urban and Environmental Engineering, \\ Kyushu University, Japan
}

\begin{abstract}
Although many river restoration projects have been conducted in Japan, reliable results concerning the environmental assessment methods have not yet been obtained. Therefore, we conducted a study on the Kamisaigo River, a tributary of the Saigo River, which flows through the city of Fukutsu, Japan. The study river had been canalized for alignment, with concrete revetment of the river bank, in turn reducing the biological function of the river. In 2007, Fukutsu City Government initiated a restoration program to improve the environmental quality of the river. The aim of the present study was to determine the optimal method of evaluating the river environment. We surveyed the fish fauna and physical environment to assess the environmental condition of the river using a fish index developed by Kyushu University. This index incorporates 16 indicators based on fish behaviour and life history (e.g. preferred flow rate, environmental requirements for spawning). The survey results from seven sampling stations indicated that the environmental quality of the river substantially varies across sites. Due to the presence of a diversity of habitat types, station 1 was in good condition compared with the other six stations. In contrast, stations 2 and 6 were in moderate to poor condition with low values of at least one indicator. Using these assessment results, we will be able to determine the specific weaknesses that affect the condition of a given station. Based on these findings, a restoration and improvement program should be established to accomplish several goals,
\end{abstract}


including restoring the flood plain, incorporating a variety of flow rates, and enhancing vegetation for fish spawning.

Keywords: fish index, rehabilitation plan, environmental variation.

\section{Introduction}

Biological integrity is "the ability to support and maintain a balanced, integrated adaptive assemblage of organisms having species composition, diversity, and functional organization comparable to that of the natural habitat of the region" (Karr and Dudley [5]). The index of biological integrity (IBI) provides a synthesis of diverse biological information that numerically depicts associations between human influences and biological attributes. The IBI is composed of several biological attributes or metrics that are sensitive to changes in biological integrity caused by human activities. The multi-metric (a compilation of metrics) approach compares what is found at a monitoring site with what is expected using a regional baseline condition that reflects little or no human impact (Karr [4]).

Although many river restoration projects have been conducted in Japan, reliable results by which to determine the appropriate environmental assessment methods have not yet been obtained. In 2007, the Fukutsu City Government initiated a restoration program to improve the environmental quality of the Kamisaigo River. Fish species are essential to the successful functioning of this river ecosystem; thus, any changes that reduce the fish population size, community composition, or the availability of aquatic animals will affect all facets of the ecology of the Kamisaigo River. Fish are excellent indicators of watershed health because (1) they spend their entire life cycle in aquatic habitats, (2) they differ in their tolerances to the amount and types of pollution, (3) fish are easy to collect with the correct equipment, (4) they are relatively long lived up to several years, and (5) they are easy to identify in the field (EPA [2]).

Therefore, the objectives of the present study were to determine the optimal methods for assessing the river environment and to evaluate river health based on fish ecological health integrity. Our results will contribute to the development of a rehabilitation plan, and will enhance conservation efforts. Preserving an ecologically sound environment involves the maintenance of the diversity and productivity of aquatic species; thus, current research must continually upgrade the value and dependability of habitat assessment methods.

\section{Study area}

The Kamisaigo River, a small tributary (second order:33 $45^{\prime} 24.29$ and $33^{\circ} 45^{\prime} 40.16 \mathrm{~N}$ and $130^{\circ} 29^{\prime} 55.52$ and $130^{\circ} 29^{\prime} 25.15 \mathrm{E}$; Figure 1) is characterized by a water surface width of 2.4-6.8 $\mathrm{m}$ and water depths ranging from $11.2-30.2 \mathrm{~cm}$. The study area was an $800 \mathrm{~m}$ reach of the river located at the confluence with the Saigo River, in Fukutsu, Fukuoka Prefecture, Japan. The primary use of this river is irrigation, and the majority of surrounding land is dedicated to residential and commercial uses. The river has been canalized and 
covered with concrete lining which has subsequently damaged the physical and biological functions of the river. In addition, the river is flood-prone, and the overall environment has become inhospitable for aquatic life. Currently, the river environment does not attract recreational activities; thus, it remains disconnected from the community. The basic policies of the Fukutsu restoration program for the river intend to create a more aesthetic natural river habitat, improve the general environment for aquatic organisms, and foster a strong connection between the local community and the river environment. However, the details of restoration plan design remind under discussion.

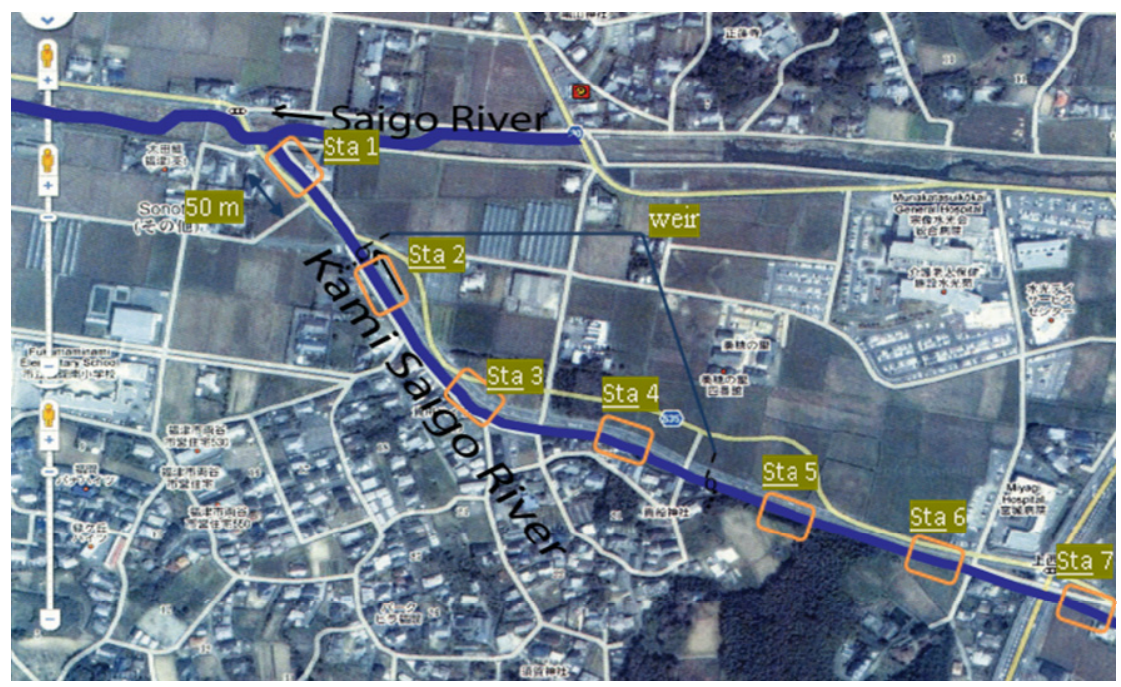

Figure 1: $\quad$ Study area (Kamisaigo River in Fukuoka, Japan).

\section{Methods}

\subsection{Fish sampling}

In the autumn (October-November) of 2009, fish assemblages were sampled along the $800 \mathrm{~m}$ reach of the river using a backpack electro fisher (LR-24 SmithRoot, Vancouver, WA, USA). Every $50 \mathrm{~m}$ stretch was blocked with (seine) netting to ensure population enclosure. To maximize the capture of fish, we attempted to sample equally both river lines and a variety of habitat types. We used intermittent shocking when approaching structures such as downed trees, and patches of vegetation. Once captured, fish were measured (total number of fish, length, weight) and then released alive. Fish standard length was measured to the nearest millimetre and weight was measured to the nearest gram. All fish $>20 \mathrm{~mm}$ standard length collected within the sample reach were identified to species (or subspecies) (Figure 2). 


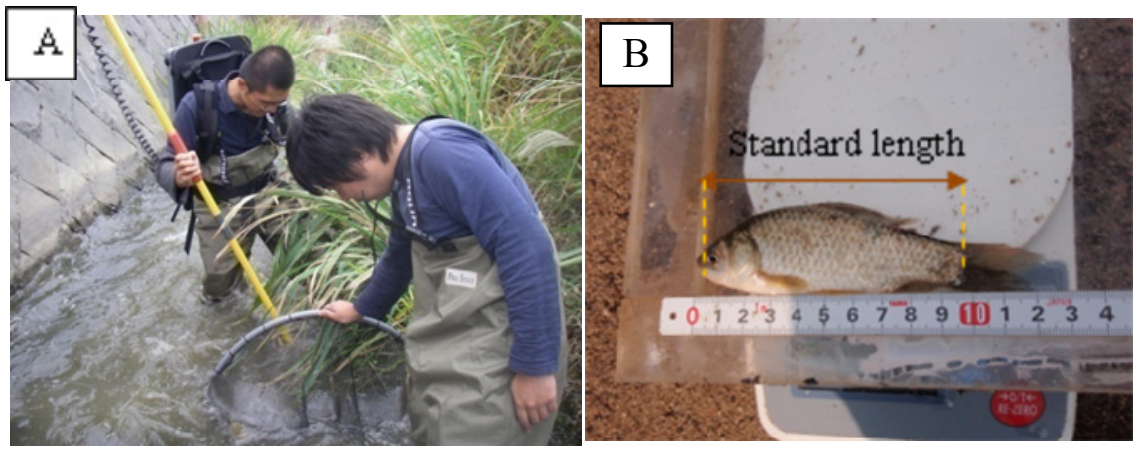

Figure 2: Fish sampling. A. Netting fish after they had been shocked; B. Weighing and measuring the length of fish.

\subsection{Data analysis}

To evaluate the health of the fish assemblage in the Kamisaigo River, we calculated 16 regionally developed indices using the ecological features of fish (Nakajima et al. [3]). These indicators are typically evaluated with respect to criteria such as the environmental significance of the problem area and data availability. In addition, the fish species must be listed and scored. Scoring criteria were developed using high quality historical data. To verify sampling efficacy, we compared our final species list with those developed by Kyushu University, and when available, with those from previous fish collections. The Fish Biological Integrity Index (FBII) was calculated using the following equation:

where:

$$
\mathrm{FBII} i j=10 \times \mathrm{Nk} i j / \mathrm{Ns} j
$$

-FBII $i j$ : is the Fish Biological Integrity Index, $i$ : is station number, $\mathrm{j}$ : is axis number

-Nkij: is the number of species at station $i$ in the Kamisaigo River of the $j$ th axis

-Nsj: is the number of species of the $j$ th axis caught in the Kamisaigo River system

The FBII scores adequately represent characteristics of river integrity and can be used to determine which rivers (or segments of rivers) warrant restoration and the appropriate methods for restoration. The calculation of total FBII was conducted in three steps: (1) each FBII $i j$ were calculated, (2) the mean of each axis value was calculated $\left(\frac{\sum_{k=1}^{7} \mathrm{FBII} k j}{7}\right)$, and (3) the FBII $i j$ of each station was suggested through averaging the FBII $j$ of each axis. 


\section{Results and discussion}

A total of 746 fishes of 16 species were collected from the Kamisaigo River. Subsequently, the fish index developed by Kyushu University (Nakajima et al. [3]) was used to compare the condition of sampling stations. The index was composed of the following 16 indicators based on ecological characteristics of fish behaviour and life history; (1) native species, (2) exotic species, (3) endangered species, (4) freshwater species, (5) brackish water species, (6) swimming species, (7) bottom-dwelling species, (8) moving-current species, (9) slow-current species, (10) main-stream species, (11) floodplain species, (12) species that spawn in aquatic vegetation, (13) species that spawn on muddy bottoms, (14) species that spawn on gravel bottoms, (15) species that spawn on rocky bottoms, and (16) species that spawn in bivalve.

These metrics assess the species-richness component of diversity and the health of resident taxonomic groupings and habitat guilds of fishes.

Axes 1 and 2. The origin of the fish community (native and exotic species). Substitutes (Table 1): Number and identity of Anguilla japonica, Zacco platypus, Carassius auratus buergeri, Pseudogobio esocinus, Zacco temmincki, Carassius auratus langsdorfii, Cyprinus carpio, Rhinogobius giurinus, Rhinogobius sp. CB, Gymnogobius petschiliensis, Phoxinus oxycephalus, Rhinogobius sp. OR, Misgurnus anguillicaudatus, Odontobutis obscura, Oryzias latipes and Cobitis matsubarae. The characteristics of fish community alterations depend on the type of river sector involved; small rivers of the basin serve as refuge zones for the native community and are currently of fundamental importance for maintaining biodiversity (Lorenzoni et al. [6]).

Axis 3. Endangered Species. Substitutes (Table 1): Number and identity of Anguilla japonica, Misgurnus anguillicaudatus, Oryzias latipes, and Cobitis matsubarae. An endangered species is a population of organisms that is at risk of becoming extinct because it is either few in number or threatened by changing environmental or predation parameters. If endangered species are present, the protection of streams and rivers that are still healthy is also crucial (Trust for Public Land [12]). The goal of conservation efforts should be to create and expand programs to preserve endangered species and maintain biodiversity.

Axes 4 and 5. Life history type (freshwater and brackish water species, respectively). Substitutes (Table 1): Number and identity of freshwater species: Zacco platypus, Cyprinus carpio, Carassius auratus langsdorfii, Carassius auratus buergeri, Zacco temmincki, Phoxinus oxycephalus, Cobitis matsubarae, and Oryzias latipes. Number and identity of Anguilla japonica, Gymnogobius petschiliensis, Rhinogobius giurinus, Rhinogobius sp.CB, Rhinogobius sp.OR, Misgurnus anguillicaudatus, Odontobutis obscura, and Pseudogobio esocinus. These species of freshwater fish spend their entire or parts of their lives in freshwater bodies, such as lakes; or rivers with salinity levels lower than $0.05 \%$.

About $41 \%$ of fish species were found in fresh water.

Axes 6 and 7. Swimming layer (swimming and bottom-dwelling species, respectively). Substitutes (Table 1): Number and identity of swimming species: Zacco platypus, Carassius auratus buergeri, Zacco temmincki, Carassius 
auratus langsdorfii, Cyprinus carpio, and Oryzias latipes. Swimming, the most general behaviour pattern of fish, involves the integrated effects of numerous physiological processes (Schreck [11]). The overall pattern of swimming; was assessed as swimming into shallow water, swimming lethargically at the surface, lying listlessly on the pond or tank bottom, floating downstream, or swimming erratically (Plumb [9]). Number and identity of bottom-dwelling species: Anguilla japonica, Pseudogobio esocinus, Rhinogobius giurinus, Rhinogobius sp.CB, Gymnogobius petschiliensis, Rhinogobius sp.OR, Misgurnus anguillicaudatus, Odontobutis obscura and Cobitis matsubarae.

Table 1: Index of fish ecological health integrity developed by Kyushu University.

\begin{tabular}{|c|c|c|c|c|c|c|c|c|c|c|c|c|c|c|c|c|}
\hline Species & \begin{tabular}{|l|} 
Axes \\
native
\end{tabular} & $\begin{array}{l}\text { Axes } 2 \\
\text { exotic }\end{array}$ & $\begin{array}{c}\text { Axes3 } \\
\text { endangered }\end{array}$ & $\begin{array}{l}\text { Axes } 4 \\
\text { fresh } \\
\text { water } \\
\end{array}$ & $\begin{array}{l}\text { Axes5 } \\
\text { brackish } \\
\text { water }\end{array}$ & $\begin{array}{c}\text { Axes6 } \\
\text { swimming }\end{array}$ & $\begin{array}{l}\text { Axes? } \\
\text { bottom- } \\
\text { dwelling }\end{array}$ & $\begin{array}{l}\text { Axes } 8 \\
\text { moving- } \\
\text { current }\end{array}$ & $\begin{array}{l}\text { Axes9 } \\
\text { slow- } \\
\text { current }\end{array}$ & \begin{tabular}{|c|} 
Axes 10 \\
main- \\
stream \\
\end{tabular} & \begin{tabular}{|l|} 
Axes 11 \\
flood \\
plain
\end{tabular} & \begin{tabular}{|c|} 
Axes 12 \\
spawn in \\
aquatic \\
vegetation
\end{tabular} & \begin{tabular}{|c|} 
Axes 13 \\
spawn on \\
muddy \\
bottoms
\end{tabular} & $\begin{array}{c}\text { Axes } 14 \\
\text { spawn on } \\
\text { gravel } \\
\text { bottoms }\end{array}$ & $\begin{array}{c}\text { Axes } 15 \\
\text { spawn on } \\
\text { rocky } \\
\text { bottoms }\end{array}$ & $\begin{array}{l}\text { Axes } 16 \\
\text { sparwn in } \\
\text { bivalve }\end{array}$ \\
\hline Annuilla japonica & 0 & & 0 & & 0 & & 0 & 0 & & 0 & & & & & & \\
\hline Cyprinus carpio & 0 & & & 0 & & 0 & & & 0 & 0 & & 0 & & & & \\
\hline Carassius aurratus langsdorfii & 0 & & & 0 & & 0 & & 0 & & 0 & & 0 & & & & \\
\hline Carrassius auratus buergeri & 0 & & & 0 & & 0 & & & 0 & 0 & & 0 & & & & \\
\hline Zacco platypus & 0 & & & 0 & & 0 & & 0 & & 0 & & & & 0 & & \\
\hline Zacco temmincki & 0 & & & 0 & & 0 & & 0 & & 0 & & & & 0 & & \\
\hline Phorimus oxycephalus & 0 & & & 0 & & & & 0 & & 0 & & & & 0 & & \\
\hline Psendogobio esocinus & 0 & & & & 0 & & 0 & 0 & & 0 & & & & 0 & & \\
\hline Misgurnus anguilicaudatus & 0 & & 0 & & 0 & & 0 & & 0 & & 0 & & 0 & & & \\
\hline Cobitis matsulbarale & 0 & & 0 & 0 & & & 0 & 0 & & 0 & & & & 0 & & \\
\hline Oryzias latipes & 0 & & 0 & 0 & & 0 & & & 0 & & 0 & 0 & & & & \\
\hline Odontobutis obscilla & 0 & & & & 0 & & 0 & & 0 & & 0 & & & & 0 & \\
\hline Gymnogobius petschiliensis & 0 & & & & 0 & & 0 & & 0 & 0 & & & & & 0 & \\
\hline Rhinogobiuss giurinus & 0 & & & & 0 & & 0 & & 0 & 0 & & & & & 0 & \\
\hline Rhinogobius sp.CB & 0 & & & & 0 & & 0 & 0 & & 0 & & & & & 0 & \\
\hline Rhinogobiuus sp. OR & 0 & & & & 0 & & 0 & 0 & & 0 & & & & & 0 & \\
\hline Total & 16 & 0 & 4 & 8 & 8 & 6 & 9 & 9 & 7 & 13 & 3 & 4 & 1 & 5 & 5 & 0 \\
\hline
\end{tabular}

Axes 8 and 9. Suitable current type (moving-current species and slow- current species, respectively). Substitutes (Table 1): Number and identity of movingcurrent species: Anguilla japonica, Carassius auratus langsdorfii, Zacco platypus, Zacco temmincki, Phoxinus oxycephalus, Pseudogobio esocinus, Cobitis matsubarae, Rhinogobius sp.CB, and Rhinogobius sp.OR. Number and identity of slow-current species: Cyprinus Carpio, Carassius auratus buergeri, Misgurnus anguillicaudatus, Oryzias latipes, Odontobutis obscura, Gymnogobius petschiliensis, and Rhinogobius giurinus. Flow rate determines the range of available microhabitat conditions that satisfy or are essential for the needs of different species. The density of water can make it difficult for some species of fish to move but many species can move very smoothly and quickly. In terms of the affinity for flowing water, species were considered either 
rheophilic or nonrheophilic in their habitat use. Rheophilic species typically occur in fast-flowing habitats, whereas nonrheophilic species commonly use slow-flowing habitats. Rheophilic species are typically round in cross-section and are strong swimmers (Angermeier and Davideaunu [7]).

Axes 10 and 11. Habitat type (main-stream and floodplain species, respectively). Substitutes (Table 1): Number and identity of main-stream species: Anguilla japonica, Cyprinus carpio, Carassius auratus langsdorfii, Carassius auratus buergeri, Zacco platypus, Zacco temmincki, Phoxinus oxycephalus, Pseudogobio esocinus, Cobitis matsubarae, Gymnogobius petschiliensis, Rhinogobius giurinus, Rhinogobius sp.CB, and Rhinogobius $s p . O R$. Main-stream fish species are generally long-lived and are common in canal habitats and other deepwater areas. Main-stream and floodplains can support particularly rich ecosystems, in terms of both the quantity and diversity of fish species. Number and identity of floodplain species: Misgurnus anguilicaudatus, Oryzias latipes, and Odontobutis obscura.

Axes 12-16. Spawning ecology type (spawn in vegetation, muddy bottoms, gravel bottoms, rocky bottoms and bivalves, respectively). Substitutes (Table 1): Number and identity of species that spawn in vegetation: Carassius auratus buergeri, Carassius auratus langsdorfii, Cyprinus Carpio, and Oryzias latipes. Number and identity of species that spawn on muddy bottoms: Misgurnus anguilicaudatus. Number and identity of species that spawn on gravel bottoms: Zacco platypus, Zacco temmincki, Phoxinus oxycephalus, Pseudogobio esocinus, and Cobitis matsubarae. Number and identity of species that spawn on rocky bottoms: Odontobutis Obscura, Gymnogobius petschiliensis, Rhinogobius giurinus, Rhinogobius sp.CB, and Rhinogobius sp.OR. Spawning is the production or depositing of large quantities of eggs in water. The availability of suitable spawning habitat at the appropriate locations is a prerequisite for the successful reproduction and persistence of a population. We recognized five types of spawning substrates: mineral (e.g., sand, gravel, bedrock), vegetation, general (either mineral or vegetation), pelagic, and other (species that do not lay eggs in the stream). We refer to species that spawn on mineral substrates as lithophils; all other species were non-lithophils (Angermeier and Davideaunu [7]). Although we do not provide fully validated indices, we identify the steps needed to develop reliable, defensible indices.

Figures 3 and 4 present the characteristics of the Kamisaigo River natural environment.

Station 1 (Figure 3A). This station consisted predominantly (91\%) of fastcurrent shallow habitats (riflles, rapids [two locations]), runs [4] and glides [6]) and very few slow-current habitats (pools) about $16 \mathrm{~cm}$ in depth (Figure 4).

Some vegetation occurred in approximately $90 \%$ of the channel. A total of 15 species were found at this station: Anguilla japonica (three individuals), Carassius auratus langsdorfii (two individuals), Zacco platypus (109), Zacco temmincki (32), Rhinogobius sp.CB (95), and Rhinogobius sp.OR species (4), Cyprinus Carpio (3), Rhinogobius giurinus (11), and one individual each of Phoxinus oxycephalus, Pseudogobio esocinus, Cobitis matsubarae, Carassius auratus buergeri, Misgurnus anguillicaudatus, Odontobutis obscura, and 
Gymnogobius petschiliensis. This station was considered to be in good condition, as all axes exceeded the average values, with the exception of axes 2 and 16 (i.e., exotic species and species that spawn in bivalves, respectively), which exhibited low values.

Station 2 (Figure 3B). This station consisted entirely of slow-current shallow habitats (slacks, and/or shallows) exhibiting uniform conditions (Figure 4). Overhanging vegetation, root wads and aquatic vegetation were absent at this station. Cobities Matsubarae (31 individuals) was the only species present at this site. As a result, the index scores for station 2 were low, and it was considered to be in poor condition.
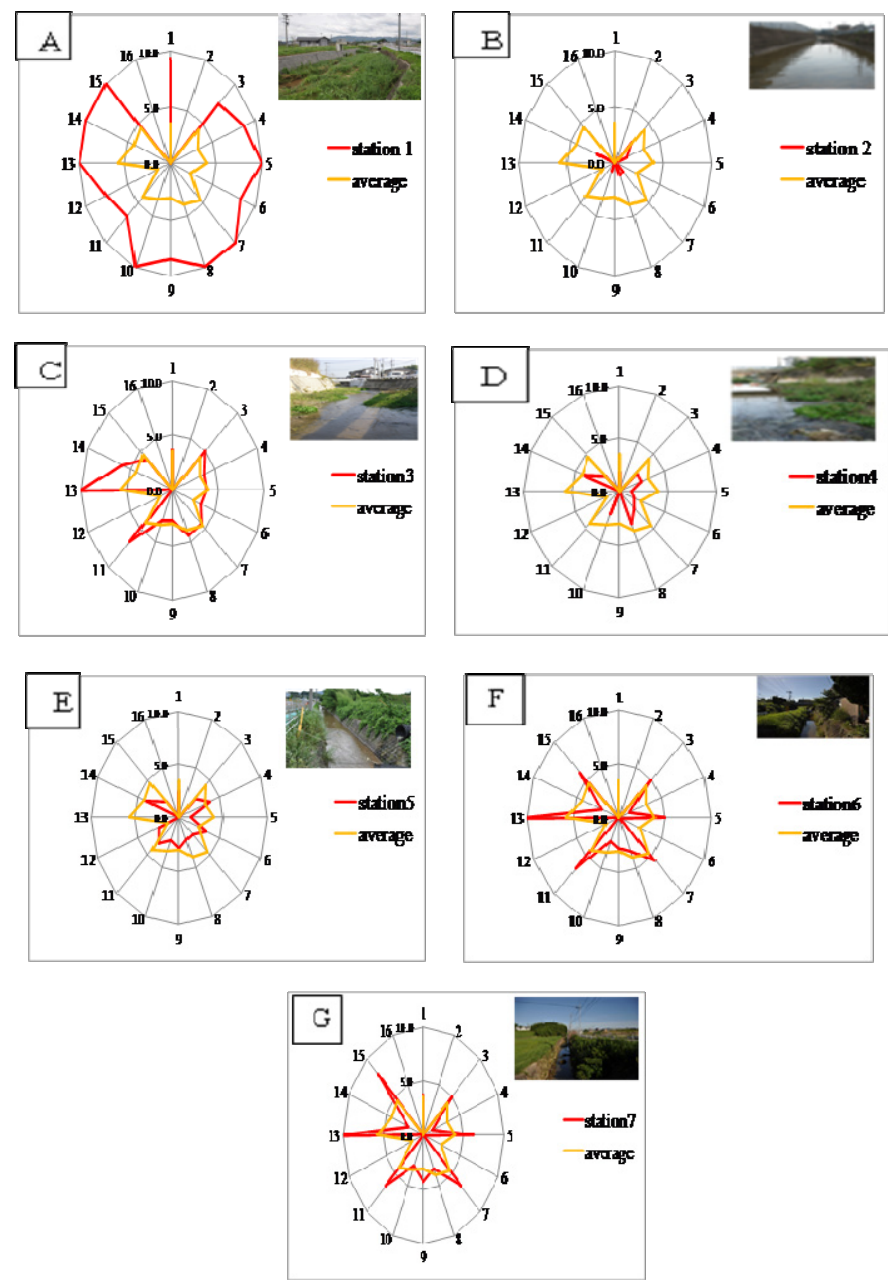

Figure 3: $\quad$ Fish biological integrity index. 


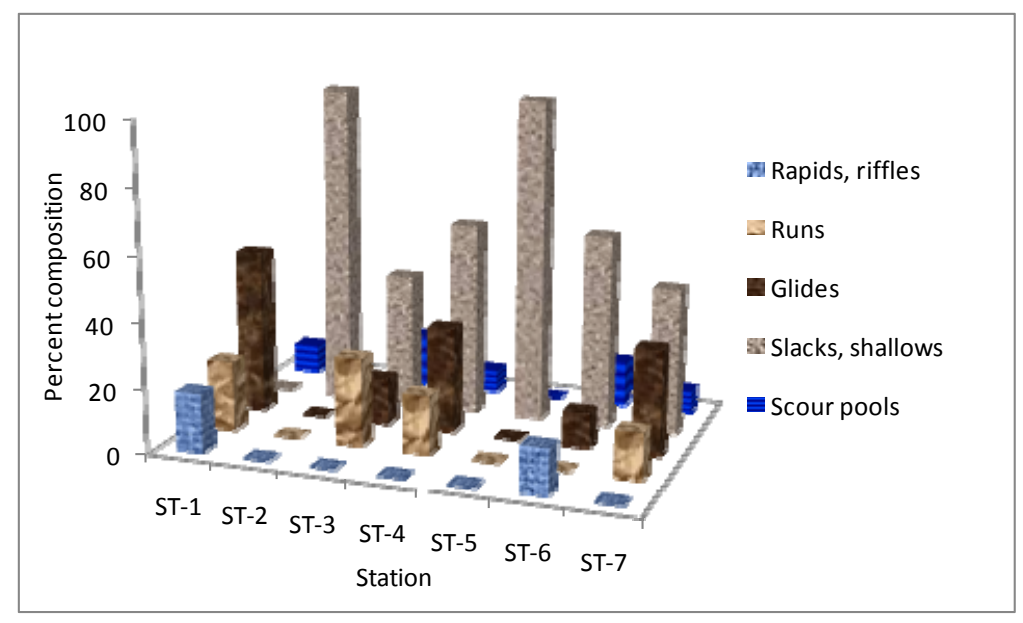

Figure 4: Composition of the flow ecology in the Kamisaigo river.

Station 3 (Figure 3C). This station comprised 42\% fast-current shallow habitats (runs [three locations], and glides [1]). $42 \%$ slacks or shallows and $16 \%$ scour pools of $20 \mathrm{~cm}$ depth. Some vegetation and aquatic vegetation were present. Five fish species were found at this station: Zacco platypus (24 individuals), Zacco temmincki (2), Misgurnus anguillicaudatus (3), Cobities Matsubarae (4), and Rhinogobius sp.CB (1). This station was assessed to be in moderate condition, as nearly all of the axes were similar to the average values. Axes 13 and 14 (i.e., fish that spawn on muddy bottoms and gravel bottoms, respectively) slightly exceed the average values.

Station 4 (Figure 3D). This station comprised 49\% slow-current shallow habitats (scour pools of $18 \mathrm{~cm}$ depth and slacks/shallows), and 51\% fast-current shallow habitats (runs [two locations] and glides [2]). Some vegetation occurred along approximately $20 \%$ of the channel. Three fish species were observed at this station: Zacco platypus (62 individuals), Rhinogobius sp.CB (5), and Cobities Matsubarae (4). This station was considered to be in poor condition, as all axes were well below the average values.

Station 5 (Figure 3E). This station was in similar condition to station 2 in that, this area consisted entirely of slow-current shallow habitats (slacks or shallows) and very uniform condition however, some overhanging vegetation and some plants were present. Four fish were observed here: Cobities Matsubarae (28 individuals), Zacco platypus (11), Odontobutis obscura (4), and Cyprinus Carpio (4). This station was assessed to be in poor condition, as nearly all of the axes were slightly below the average values. However, axes 12 (fish that spawn in vegetation) was slightly above the average value.

Station 6 (Figure 3F). This station comprised 75\% slow-current shallow habitats (scour pools 19 and $35 \mathrm{~cm}$ deep and slacks/shallows), and 25\% fastcurrent shallow habitats (riflles or rapids [two locations], and glides [1]). Overhanging vegetation, root wads and aquatic vegetation were absent. Five fish 
species were collected at this station: Cobities Matsubarae (53 individuals), Rhinogobius sp.CB (34), Odontobutis obscura (27), Misgurnus anguillicaudatus (4), and Rhinogobius sp.OR (3). This station was considered to be in moderate condition because nearly all of the axes were similar to the average values, although axes 11, 13 and 15 (i.e., flood plain species, fish that spawn on muddy bottoms and fish that spawn on rocky bottoms, respectively) were well above the average values.

Station 7 (Figure 3G). This station comprised 52\% out of slow-current shallow habitats (scour pools $19 \mathrm{~cm}$ deep, and slacks or shallows), and $48 \%$ fastcurrent shallow habitats (runs [one location], and glides [1]). Some vegetation occurred in approximately $10 \%$ of the channel. Six fish species were found at this station: Cobities Matsubarae (151 individuals), Odontobutis obscura (5), Rhinogobius sp.OR (3), and one individual each of Rhinogobius sp.CB, Misgurnus anguillicaudatus, and Gymnogobius petschiliensis. This station was considered to be in moderate condition, as nearly all axes exhibited values similar to the average values, with the exceptions of axes 5, 13, and 15 (i.e., brackish water species, fish that spawn on muddy bottoms and fish that spawn on rocky bottoms, respectively), which were clearly above the average values.

Based on Figure 3, station 3 could be restored to enhance stream naturalness and environmental functions. Removing the concrete revetment would be the first step, and the river width would be broadened twice as wide as it used to be, then connecting the stream to riparian zones by providing a sloped river bank. Thereby ecotone and continuity between terrestrial and aquatic realm are restored. Various flow conditions were rehabilitated by installing approximately one meter sized rock. Such a restoration and improvement program could also reduce fine sediment deposition in spawning and/or rearing habitats by providing spawning vegetation and recruitment gravel within the stream to improve the quality and quantity of spawning habitat (see also Figure 5).

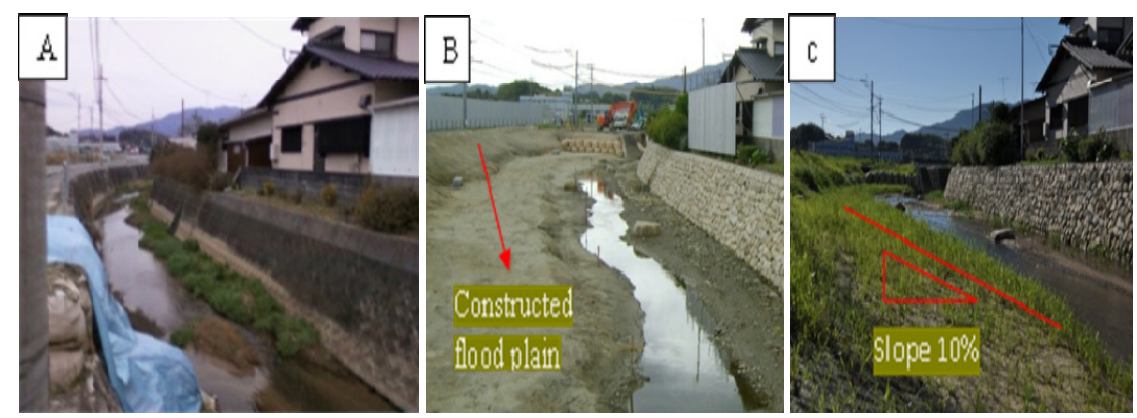

Figure 5: Station 3 condition: A. before restoration: concrete bank isolates the movement of organisms, B. Floodplain restored and bank erosion reduced, and $\mathrm{C}$. condition 3 months after restoration: installation of living and non living materials to prevent erosion. 


\section{Conclusion}

Based on results of the analysis, station 1 was in good condition compared with the other six stations, as the area around this station exhibited a diversity of habitat types. In contrast, station 3, 6, and 7 were in moderate condition, exhibiting low values on at least one indicator. Station 2, 4, and 5 were considered to be in poor condition. From this assessment, we will be able to determine which indicators are particularly weak at specific locations throughout the river. Our results also indicate that the fish biological integrity index is valuable for making preliminary diagnoses of the ecological quality of streams and rivers, thus aiding in restoration efforts and the prioritization of the rehabilitation process. This index can also be used to maximize the protection of endangered species. Thus, through the use of this preference index in combination with the characterization of the flow ecology, restoration and improvement programs can be established at the exact locations where spawning and/or rearing habitats are required.

\section{Acknowledgements}

This study was financially supported by the Watershed Management Laboratory, Department of Urban and Environmental Engineering, Kyushu University. This work was partly supported by the Research Institute of East Asia Environments, Kyushu University.

\section{References}

[1] C. B. Schreck and P. B. Moyle, Methods for fish biology, Am. Fish. Soc., Bethesda, pp. 451-489, 2002.

[2] The U.S. Environmental Protection Agency (EPA), Recommended Determination of the U.S. Environmental Protection Agency Region III Pursuant to Section 404을 on the Clean Water Act Concerning the Spruce No.1 Mine Logan County, West Virginia,2008.

[3] Jun Nakajima, Yukihiro Shimatani, Rei Itsukushima and Norio Onikura, Assessing riverine environments for biological integrity on the basis of ecological features of fish, Advanced in river engineering, Vol.16, p.449-454, 2010.

[4] Karr, J.R, Rivers as sentinels: using the biology of rivers to guide landscape management. Pp in RJ. Naiman and R.E. Bilby, eds. The Ecology and Management of Stream and Rivers in the Pacific Northwest Coastal Ecoregion, Springer-Verlag, New York, 1996.

[5] Karr, J.R. and D.R. Dudley, Draft: What is Biological Integrity, 2002.

[6] M.Lorenzoni, M.Mearelli, L.Ghetti, Native and exotic fish species in the Tibet River watershed (Umbria-Italy) and their relationship to the longitudinal gradient, Bull. Fr. Pêche Piscic. 382: 19-44, 2006. 
[7] Paul L. Angermeier \& Grigore Davideanu, Using fish communities to assess streams in Romania: initial development of an index of biotic integrity, Hydrobiologia 511: 65-78, 2004.

[8] Platts, William S.; Megahan, Walter F.; Minshall, G. Wayne., Methods for evaluating stream, riparian, and biotic conditions. GeTL. Tech. Rep. INT-138. Ogden, UT: US Department of Agriculture, Forest Service, Intermountain Forest and Range Experiment Station;. 70 p, 1983.

[9] Plumb.J.A, Health Maintenance of Cultured Fishes: Principal Microbial Diseases, CRC Press, Inc, Boca Raton, USA. p. 142-147, 1994.

[10] Rei Itsukushima, Yukihiro Shimatani, Jun Nakajima, Yoichi Kawaguchi, Segment-based ecoregions based on fish fauna as a biological indicator, Journal of Hydroscience and Hydraulic Engineering, 2010.

[11] Schreck,C.B, Physiological, behavioural, and performance indicators of stress, American Fisheries Society, 1990.

[12] The Trust for Public Land, Return on the Investment from the Land and Water Conservation Fund, 2010

[13] T. Oberdorff \& R.M. Hughes, Modification of an index of biotic integrity based on fish assemblages to characterize rivers of the Seine Basin, France, Hydrobiologia 228:117-130, 1992. 